\title{
Reading Problems among Primary School Remedial Pupils in One of Miri, Sarawak
}

\author{
Ivy Jain, Norasmah Othman \\ Faculty of Education, Universiti Kebangsaan Malaysia, \\ Bangi, Selangor, Malaysia \\ E-mail: \\ vies_jain@yahoo.com \\ Received: 9 February 2018 \\ Accepted: 8 April 2019 \\ Online First: 26 June 2019
}

\section{ABSTRACT}

Reading is a difficult skill to be mastered by children mainly remedial students prone to problems in basic reading skill. Remedial students are students with learning disabilities who have been selected to attend the Remedial Programme in their schools. This study was conducted to identify the problems faced by these students in mastering basic reading skill. Basic reading skill that is the focus of this article is the open syllables words; Consonant Vowel Consonant Vowel (KVKV). This study aimed to identify the main problems faced by students in reading open syllables words (KVKV). The study was conducted in one elementary school in the district of Miri, Sarawak involving 30 pupils in year two from remedial class. Data were collected through Diagnostic Tests, observations and interviews in the study group. The study found that the main problems were; students do not understand the basic concepts of reading clearly and the lack of motivation among the students. This study is expected to help teacher in particular remedial teachers in helping students overcome reading recovery $K V K V$ word. To improve the reading skills of pupils, the study recommended that remedial students are taught by a variety of teaching strategies such as inserting games or songs in their teaching and learning in order to cultivate their interest in reading. Teachers are also advised to constantly motivate the students so that they are eager to learn the skills of reading.

Keywords: remedial students, reading problems, reading, consonant vowel consonant vowel words (KVKV) 


\section{INTRODUCTION}

Education is one of the important assets for every individual in society. Emphasis on the importance of education, especially the literacy skills in children since the beginning of schooling should be able to help them achieve a better and balanced life especially in the workplace and community relations processes with their lives. Besides that, indirectly it will enhance economic growth and national development (Eunice Ong et al., 2015). This statement is also supported by Lim \& Sandiyao (2006) stating that the basic skill of reading, writing and counting are the first step that each pupils must master to help them in their daily lives such as reading signboards around them or purchasing items in the mall. Having a good foundation in literacy skills will benefit children's learning process and will provide them with a better future (Eunice Ong et al., 2015). However, not all students can follow the skills according to their age in the mainstream curriculum prepared by the Ministry of Education Malaysia (KPM). This problem is because there are some students who have lower achievement level from their peers due to different hereditary intelligence which cause them to take a longer time to ponder, consolidate, understand and respond with facts for any events. However, it does not mean that the students are weak in all aspects. Therefore, every child in Malaysia has the right to have education that provides them with a productive human capital that contributes to the nation's prosperity (KPM, 2013).

\section{ISSUES OF REMEDIAL STUDENT}

In the Malaysia's Education Development Plan (PPPM), The Ministry of Education (KPM) has outlined its commitment to equip the younger generation who are in school for the needs of the $21^{\text {st }}$ century. The $21^{\text {st }}$ century learning skills require creative and critical way of thinking which are one of the elements in student aspirations (PPPM, 2013). Therefore, basic reading ability is the pre-requisite element that every student need to master if they want to progress well into higher education and subsequently function well in society. This is thus a challenge for remedial students to master the basics of reading in a short time in order for them to follow the teaching and activities provided by the teacher in the mainstream education. Nevertheless, it indirectly leads to the question of how far these students 
can master the reading skills in the shortest time, which prove to be more challenging with the demands of getting them to pick up the $21^{\text {st }}$ century skills along the way as outlined by Malaysia Education Blueprint 2, with the implementation period from 2016 to 2020.

Given the many facilities and assistance provided by the Ministry of Education, reading problems that existed among students should be minimal. However, according the study by Zailani et al. (2012), there are two main issues that cause reading problems among pupils, namely lack of interest in reading and not understanding the meaning of their reading. It is also supported in the study of Tamam et al. (2011) who found that one of the factors which caused pupils to be poor in reading is the student's psychological state itself. These factors are claimed by Mohd Zainal Dirin, the Deputy Director of the Ministry of Education, to be associated to the motivation in attending school, alongside other factors such as socioeconomic background, indigenous status, geographical location, attitude and aspiration (Kang, 2012).

A study done by Tahar et al. (2010) warranted that students who have difficulties in learning should be identified as early as possible to help this group of students overcome their reading problems before they drop out of school. Early identification such as knowing whether the students are suffering from hyperactivity, autism, dyslexia or other learning difficulties will then provide teachers with an understanding of what kind of support and guidance they can offer to these students. These groups of students are more likely to require more specialised instruction (Noor Aini, 2015). Echoing these needs, the Ministry of Education, in 2010, has initiated programme for students-at-risk due to learning difficulties, termed the Literacy and Numeracy Screening (LINUS) programme. Linus is targeted at pupils of Year 1 to Year 3 who have difficulties in mastering the basic literacy and numeracy skills, who are then withdrawn from the mainstream and are guided separately until they reach the standards set by the Ministry of Education. 
The following are the descriptors for each constructs and all students are expected to achieve all 12 constructs by the end of Year 3 (KPM, 2015):

- Construct 1: Able to identify and distinguish the letters of the alphabet.

- Construct 2: Able to associate sounds with the letters of the alphabet.

- Construct 3: Able to blend phonemes into recognisable words and segment words into phonemes.

- Construct 4: Able to understand and use the language at word level.

- Construct 5: Able to participate in daily conversations using appropriate phrases.

- Construct 6: Able to understand and use the language at phrase level in linear texts.

- $\quad$ Construct 7: Able to understand and use the language at phrase level in non-linear texts.

- Construct 8: Able to understand and use the language at sentence level in linear texts.

- $\quad$ Construct 9: Able to understand and use the language at sentence level in non-linear texts.

- $\quad$ Construct 10: Able to understand and give simple instructions and directions with guidance.

- Construct 11: Able to read and understand sentences with guidance.

- Construct 12: Able to construct sentences with guidance.

In the researcher's school, same scenario is being observed. Despite receiving formal schooling for the past two years, a group of students still face much challenge in reading KVKV words. Considering the background presented, this article aims to identify factors which cause basic reading problems of KVKV word amongst Year 2 pupils. 


\section{PROBLEM STATEMENT}

Basic reading skill requires students to recognise small and capital letters well and then form the letters into words. However, these seemingly easy tasks can be challenging when a pupil suffers from hyperactivity, autism, dyslexia or other learning difficulties (Bernhard et al., 2006). Statistics presented by Ministry of Education have shown that in 2008, about 54,000 Year One pupils have been identified with low literacy skills and were enrolled in early intervention reading and writing classes (KIA2M) while a whopping 117,000 Year 4 students who did not possess basic numeracy skills were placed on 3R Remedial Programme (PROTIM). These figures are alarming, especially to the state of Sarawak, as the recent report on Linus 2.0 programme 2015 presented that 702 pupils $(1.76 \%)$ of Year 2 who are in that programme only attained Construct 1 and Construct 2. Construct 1 refers to the ability to identify and distinguish the letters of alphabet while Construct 2 involves the ability to associate sounds with the letters of the alphabet (Jabatan Pelajaran Negeri Sarawak Annual Report, 2015).

In the current school, which is situated in Miri, Sarawak, the same trend is being observed, where many pupils are falling under the standards and does not achieve higher than Construct 2. Given that the pupils have gone through a year of remedial classes and progress into Year 2, the pupils should minimally be able to achieve Construct 3, which is the ability to blend phonemes into recognisable words and segment into phonemes.

Therefore, this article aims to identify the level of mastery on reading skills amongst Year 2 pupils, and secondly is to probe deeper into the main factors which cause the basic reading problems amongst these Year 2 pupils. Basic reading skill that is the focus of this article is the open syllables words; Consonant Vowel Consonant Vowel (KVKV). 


\section{RESEARCH OBJECTIVE}

In this study the objectives are as follows:

1. To study the status of mastering KVKV's reading skills amongst Year 2 pupils.

2. To identify the main factors that cause basic reading problems amongst pupils in Year 2.

\section{RESEARCH QUESTIONS}

1. How far has the Year 2 pupils mastered the KVKV's reading skills?

2. What are the main factors which caused the problem of mastering reading skills among Year 2 pupils?

\section{METHODOLOGY}

This study involved 30 Year 2 remedial students who were in the same class at one of the primary schools in Miri. Year 2 students were intentionally chosen as these are the group of students who should have mastered Construct 2 and Construct 3 before they move into Year 3. The selection of these pupils was based on the problems they have in reading the KVKV words. The result of LINUS screening done via the standard diagnostic test in 2018 showed that this group of pupils has problems in completing Construct 1 up to Constructs 3 .

The data for this study was collected using Diagnostic Test, observation and interview. In attempting to answer research question one, the diagnostic tests was used and the research observed the pupils while they are sitting for the test. The researcher also jot down filed notes while observing the students during sitting of the test. The diagnostic test made up of oral and written component is obtained from the Special Remedial Student Teacher's Guidelines issued by the Special Education Department (KPM, 2013). This Diagnostic Test has been coordinated throughout Malaysia to test the Skill 4 (KV syllable) and Skill 5 (Merging KV and KV syllable into a word) as part of the 32 special teaching and learning skills of the Malay Language need to be mastered by pupils. This Special Programme aimed to look at whether there is a weakness in students' KVKV's reading skill. 
Besides the diagnostic test, observation and semi-structured interview methods were also carried out in triangulating the findings from diagnostic test as the participants of this study are students who cannot read and write well. Observation intended to focus on the body language of the pupils and how the pupils construct two KVKV words. They are asked about the difficulties they face and their feelings while the teacher get them to spell the KVKV words.

The score from the diagnostic test was analysed using the marking scheme prepared by the Special Education Department, while the field notes and interview transcripts were analysed for categories which address the research questions.

\section{FINDINGS}

\section{How far has the Year 2 pupils mastered the KVKV reading skills?}

The result of the study showed that only $11 \%$, or four out of 30 pupils were able to provide answers and score the minimum standard in passing Construct 2 and 3 . The other $89 \%$ who did not meet the standard showed that pupils' performance was still weak in the skills of completing $\mathrm{KV}$ syllables and $\mathrm{KVKV}$ words. The analysis revealed that pupils find questions of Construct 2 as more challenging as they are required to write one $\mathrm{KV}$ syllabus to form the word KVKV based on the given picture, as compared to Construct 3 which test the pupils' skill in the open KVKV syllabus by selecting the existing KVKV word based on the given picture. These are aligned to the findings which revealed that the pupils answered wrongly for more items under Construct 3 rather than Construct 4.

The observation during the diagnostic test is congruent with what has been reported as it was noted that pupils seemed restless while answering Construct 3-related questions and looked at the teacher for answers when encountering most of Construct 3-related questions. Through observation and interviews with ten students, it was found that most pupils face problems in spelling KV syllabus and pronouncing KVKV words orally. Most students find the spelling words difficult and some do not respond directly when 
queried. Furthermore, through observation, students were seen to be anxious when asked to spell and they started to lose focus even though interviews only test pupils' ability in spelling three KVKV words.

It was also found that most pupils had the problem of spelling words of $k u d a$ (horse) and labu (pumpkin) while students were more likely to answer correctly in items involving words like gigi (teeth) and sudu (spoon). This findings resonated with what was reported by Tiong and Zaidatun (2008), which advocated that pupils are more likely to remember words associated with things that they commonly encounter with in their daily lives, as opposed to things they rarely see. These familiar experiences contributed to the active learning process and allow information to be retained longer and retrieved faster.

\section{What are the main factors which caused the problem of mastering reading skills among Year Two pupils?}

The semi structured interview was guided by two fundamental questions which are as followed.

- Did you find completing the task challenging? If yes, can you explain what is difficult?

- Do you like reading?

The analysis of the interview data which focused on causes of mastering reading skills resulted in two categories namely; (i) the weak basic concept of reading and (ii) lack of self-confidence.

\section{Category one: The weak basic concept of reading}

The first category describes the findings on which the pupils explained that they find reading and spelling KVKV words as challenging due to their lack of understanding on constructing words and subsequently reading them. Instead of seeing a word as a combination of a syllable with another syllable, the students admitted that they memorised the entire words and not remembering the individual syllable. For example, one of the participants mentioned the following. 
"Saya tak tahu, cikgu. Yang ni saya tak belajar. Saya ingat yang cikgu ajar minggu lepas sahaja." (I do not know the answer to this. I did not learn this. I can only remember what you taught me last week.) (Pupil 8)

Another pupil who had the similar strategy in remembering words was also quoted as saying: (Pupil 3)

"Cikgu, yang ini saya tak hafal." (Teacher, I did not memorise this.)

For other students, they tend to keep mum when asked to pronounce the KVKV words, but when asked if they do not know because they did not memorise the words, they simply nodded. The findings suggested an insight about the strategy of memorising words used by the pupils to answer the diagnostic test, which appeared to be detrimental to their learning if there has been no intervention on correcting their way of learning the words. Memorisation will not work when they need to pronounce words of other KVKV combinations.

\section{Category two: Lack of Self-confidence}

The second category describes the lack of self-confidence when it comes to reading. Apart from the observation that the pupils appear to be quiet throughout the test because of their inability to provide answers, the interview sessions suggest that these are caused by the lack of confidence when it comes to pronouncing words that they are not sure of. With deeper probing and encouragement, the researcher who is also their class teacher for two years, were able to find out that they are self-blaming for being slow. An excerpt of interview with one of the pupils is as followed:

"Tak tahu la, cikgu. Saya bukan pandai... semua orang cakap saya tak pandai. Buat apa susah-susah tanya saya. Saya tak tahu." (I have no idea. I am not clever... everyone said that I am not clever. Don't bother asking me. I do not know.) (Pupil 1)

In the case of Pupil 1 and majority of the pupils, it was found that the remarks passed about them for being in the remedial classes challenges their belief about their ability. The lack of confidence in advancing themselves in learning, specifically in the KVKV word formation was apparent. 


\section{DISCUSSION AND CONCLUSION}

As outlined by the Special Remedial Malay Language Teaching Guide (2012), pupils of Year Three need to master 32 basic skills in Bahasa Melayu in order to master good reading skills. Therefore, students who are taught to read should understand the concept of a built-in word rather than the concept of smooth reading by the teacher, as stated by Zailaini et al. (2012). At the basic level, the pre-requisite for mastery in reading are mastering the vocabulary of five vowels and 21 consonants. Then, pupils are required to understand the concept of word formation using vowels and consonant letters. However, there are students who memorise words given by their teachers without an understanding of how the words are formed. Additionally there are also some students who have dyslexic problems where they are mistaken for the letter $b$ with $d$ as well as $j$ with $g$ which cause problems in their reading.

Pupils have diverse intelligence in each of them. Therefore, teachers need to ensure that these weak students are interested in what they learn. Teachers need to be creative and provide a variety of teaching activities in order to attract students to reading (Abdull Sukor, 2012). Siti and Najeemah (2012) whose study is consistent with the findings of this study encouraged 'play' approach in teaching and learning. Additionally, teachers should motivate and communicate expectations consistently so that these pupils can gradually improve their self-esteem. It is also supported in the study of Rizalina (2014), which emphasized the role of teachers in promoting student motivation in which pupils should be given the opportunity to express their feelings and enhance their creativity in order to improve pupils' cognitive and psychomotor developments.

The basic problem of reading the word KVKV should be seen as a problem that has a major impact on the individual pupil. If it is not overcome, it will make it difficult for the student to master reading skills. In addition, knowing the weakness of each student, indirectly, teachers can also identify the characteristics of students with other learning disabilities in which the students of this category need special teaching method according to the level of their skills to ensure that they are able to maximise the benefits of knowledge delivered by teachers. Teachers also need to be proactive in identifying these remedial students so that they are not left behind which 
will indirectly bring down their self-confidence. Additionally, it is necessary that teacher provide early intervention so that the student's shortcomings do not remain with the students until the end of their schooling years.

\section{REFERENCES}

Abdull Sukor Shaari \& Kalaidevi (2015). Kesan Pendekatan Pembelajaran Masteri Terhadap Pencapaian Kemahiran Membaca Bahasa Melayu Murid Pemulihan Sekolah Rendah. Kuala Lumpur: Fajar.

Bernhard, J. Cumin, J., Campoy, A., Ada, A. \& Winsler, A. (2006). Identity texts and literacy development among preschool English language learners: Enhancing opportunities for student-at-risk for learning disabilities. Teachers College Record, 108(11), 2380-2405.

Eunice Ong, Fauzan Izzati, Nor Hafizah Anwardeen \& Fatin Hazirah (2015). Suitability of the literacy and numeracy screening (LINUS) 2.0 Programme in assessing children's early literacy. The Malaysian Online Journal of Education Science, 3(2), 36-44.

Garis Panduan Perlaksanaan Pemulihan Khas. (2012). Bahagian Pendidikan Khas. Putrajaya: Kementerian Pendidikan Malaysia.

Kong, S. C. (2012). LINUS programme for early learning. The Star Online. Retrieved from http://www.the star.com.my/news/nations.2012/09/05/ linus-programme-for-early-learning.

Laporan Tahunan Pelan Pembangunan Pendidikan Malaysia (2013). Putrajaya: Kementerian Pendidikan Malaysia.

Laporan Tahunan Jabatan Pendidikan Negeri Sarawak. (2015). Kuching: Jabatan Pendidikan Negeri Sarawak.

Lim, F. L. \& Sandiyao (2006). Curriculum relevance for primary Pupils with learning difficulties: Using achievement scores and behaviouralemotional strength quotients as indicators. Jurnal Pendidikan Universiti Malaya, 5, 46-56. 
Noor Aini \& Zamri Mahamod (2015). Pengubahsuaian dalam pengajaran Bahasa Malaysia bagi murid bermasalah Pembelajaran. Jurnal Pendidikan Malaysia, 40(1), 63-73.

Rizalina Mat Razi (2014). Peranan guru dan ibubapa merangsang perkembangan sosioemosi kanak-kanak melalui aktiviti bermain. Unpublished master dissertation, Universiti Pendidikan Sultan Idris.

Siti Fatimah \& Najeemah Mohd Yusuf(2012). Kemahiran membaca kanakkanak dalam aplikasi pendekatan belajar melalui bermain. Jurnal Pendidikan, 5, 56-78.

Tamam Timbang (2011). Faktor dan masalah membaca dalam kalangan murid sekolah rendah kerajaan di Brunei Darulsalam. Jurnal Pendidikan Bahasa Melayu, 1(1), 89-107.

Tiong, L. L. (2008). Pendekatan pembelajaran kemahiran membaca menerusi lagu dan muzik berasaskan komputer bagi murid tahun satu. Unpublished master dissertation, Universiti Teknologi Malaysia.

Zailani Zakaria (2010). Strategi pengajaran kemahiran membaca kepada kanak-kanak prasekolah. Unpublished master dissertation, Universiti Kebangsaan Malaysia. 